\title{
THE INFLUENCE OF CREATIVE INDUSTRIES ON THE SOCIO- ECONOMIC DEVELOPMENT OF REGIONS IN POLAND
}

\author{
Łukasz WRÓBLEWSKI \\ Academy of Business in Dąbrowa Górnicza
}

\begin{abstract}
In hereby study, a cultural sector was distinguished from industries of the culture and creative industries, specially taking into account the definition of these notions. On the basis of studies of the Institute for Structural Research in Warsaw, a sector of creative industries in Poland was presented. An attempt to determine the influence of creative industries on the social-economic development of the region was also made. It was pointed that the culture and creative industries drawing from it contribute to an increase in endogenous ability of the region to react to changes occurring under the influence of exogenous factors.
\end{abstract}

\section{KEY WORDS}

culture, industries of the culture, creative industries, development of the region

\section{JEL CLASSIFICATION}

R11

\section{INTRODUCTION}

Going up the path of economic development - increasingly innovative, will not be possible without using economic chances sticking in creative industries. In modern societies creative industries are a most quickly developing segment of public goods and services market, they constitute the very essential but still poorly recognised area of research. These industries create big economic chances. Because they are included mainly in branches of dematerialised production (of symbols, meanings and experiences) typical for the post-industrial era, reaching the high return, having an enormous developmental potential. It is impossible to overrate the significance of creative industries for the social-economic development of the region. On account of their innovation, permanent production of new goods and services they are one of most dynamically developing sectors of the labour market. Simultaneously they are very attractive for countries suffering from the unemployment, because the majority of them are laborious fields serving to create new professions and new jobs.

The main purpose of this study is determining the influence of creative industries (through industries of the culture and the artistic creativity) on the socio-economic development of the region. Base sources of the research on the influence of creative industries on socio-economic development of regions in Poland used in the study can be to divided to theoretical and empirical ones. The theoretical base used within the framework of this study was a critical analysis of the literature on the subject. The empirical base, which had a secondary character, a fact that the sphere

\footnotetext{
${ }^{6}$ Correspondence address: Łukasz Wróblewski, Ph.D.; 1wroblewski@wsb.edu.pl, Academy of Business in Dąbrowa Górnicza, Poland.
} 
of the culture is an object of many researches was used - among others, an analysis of the data of the Central Statistical Office of Poland in Warsaw and the Institute for Structural Research in Warsaw was made.

\section{THE CULTURE, INDUSTRIES OF THE CULTURE AND CREATIVE INDUSTRIES}

In the research of the culture or the creative industries, a situation of lack of agreement in basic theoretical and methodological matters prevails for quite some time, which is letting know about itself at least in the diverse way of understanding of main notions, serving to describe the sociocultural reality, its phenomena and processes. That is why it is also very important to outline in a possibly precise manner, the borders of such notions as: "culture", "industries of the culture", or "creative industries".

There are many meanings of the term "culture", which is reflected in more than a thousand different definitions of culture formulated in humanistic sciences. Culture is one of the fundamental concepts of contemporary humanities, and even though, the use of the term was popularized widely only in the twentieth century, its etymological origin goes back to classical antiquity (Grad, Kaczmarek, 2005). Making a diagnosis of the impact of culture, and consequently creative industries on the socio-economic development of the region, we are forced to define the concept of culture delineating areas of characterized phenomena. This term is differently understood, and in addition, it is possible to distinguish three approaches that apprehend it. First, the broadest, is characteristic for the theory of cultural studies and social science, which defines the culture appealing to notions of the whole of human products and practices, the symbolic communication and the values shared in societies and communities (Kłoskowska, 1983). In the second, narrower meaning, the culture appeals to widely understood art (plastic arts, exhibited arts, literature and other) (Kmita, 1982). The third approach refers to the second, i.e. narrow understanding the culture, however, it is based on comprehending the sector or the industry, which is making it useful for economic analyses, and the most functional for needs of this study (Kolb, 2005).

The term "industries of the culture", for the first time appeared in "Dialectic of the Enlightenment" by Theodor W. Adorno and Max Horkheimer in 1947 and at first it was used in the context of the criticism of the modern, mass approach towards entertainment. Combination of words "culture" and "industry" was supposed to shock the recipient and to disavow the popular forms of entertainment, such as the press of low flights, the film or the music addressed to a mass audience (Adorno, 1991). At present the pejorative overtone of the expression "industries of the culture" was lost and it is used for determining these industries, which "combine creating, production and commercialisation of a product of immaterial and cultural character, and the product (its contents) are usually protected by copyright" (UNESCO, 2005). These are the branches of business set to producing different cultural goods and services, and industries which the production leans itself on industrial copying original works of authors. Among them, on the Polish market one should single out above all:

- audio-visual and movie industry,

- publishing and press industry,

- music industry.

D. Thorsby suggested the concentric model of industries of the culture (Thorsby, 2008). Activities as part of industries of the culture are divided in four ranges: core creative activities associated with the art (e.g., art, musical, literary work), other core creative activities (e.g. activity of theatres, museums, Philharmonic Orchestras), more widely understood industries of the culture (e.g. publishing, television, radio) and business activities tied together (e.g. design, advertisement, fashion). The closer to the core, the higher the cultural content of products and services created by industries of the culture, as well as the greater the demand for the artistic and creative commitment (contribution of work) of persons creating them. Artists and basic fields of art are a core of the 
model (music, literature, staged and visual pieces), cultural institutions (e.g. theatres, operas, Philharmonic Orchestras, museums, libraries) are listed amongst other core creative activities. The diffusion of ideas, artistic ideas and the inspiration runs in a natural way from the core outside, reaching to business activities tied together what, with time, led to specifying creative industries (Figure. 1).

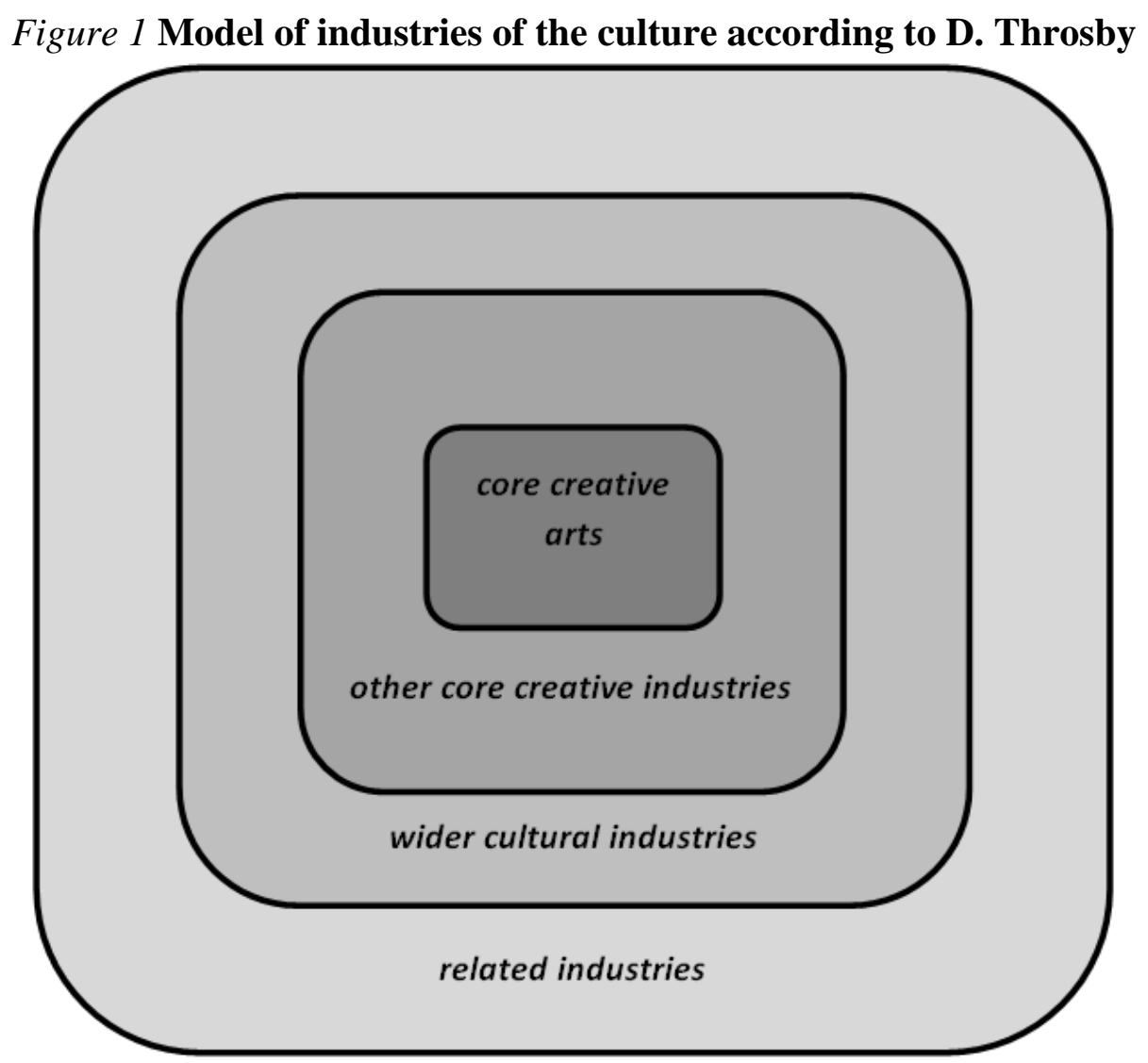

(Source: Throsby, 2008: 150)

It is assumed that in modern societies, creative industries are the quickest developing segment of public goods and services market. It is estimated, that in the United States this market (audio-visual sector, consumption of industries of the culture, software and others) constitutes over the $50 \%$ of the entire market. The concept of "creative industries" is relatively new, similarly the research on this sector constitute a new field. This notion is used from the end the 20th century, and in 2000 was popularized by Richard Caves (Caves, 2000). The very title of the book of this author already shows that creative industries act on the joint of cultural and the business activities. The notion of creative industries is a wide category, including artistic activity, cultural institutions, industries of the culture and other kinds of creative activity, based on the individual creativity, including industries using new technologies (e.g. new media) in creative activities (Klasik, 2010). The borders of this notion are drawn by the understanding of creativity and innovation, and in addition in the widest approaches these borders fade away, not letting to distinguish creative industries from other kind of intellectual activity containing a creative element, and from the innovation of all kinds, scientifictechnological included. The category of the leisure time locates industries of the culture as part of the narrow definition of the culture as the art. On the other hand, in creative industries (category wider than industries of the culture), the products meeting conditions described above are also located, but the consumption of which isn't characteristic only for the leisure time, as well as activities which recipients make use of partly in the leisure time, but which on account of the profit motive, the new type of media, the privatization of the consumption, the affiliation rather to the sphere of entertainment than the art, or for other reasons, go beyond the traditional fields of art and the activity of the institutions of culture. In Poland, Central Statistical Office joined the works on 
tidying up the sector of creative industries, which proposed the model determining areas ranked among creative industries. These are:

- architecture and the interiors design,

- publishing,

- the national legacy, libraries and archives,

- artistic education,

- the fashion and the industrial design,

- radio and musical production,

- programming,

- the advertisement and related activity,

- artistic handicraft,

- staged arts,

- visual arts.

Table 1 contains the division of the culture into principal areas, sectors and subsectors.

Table 1. The division of the culture into principal areas, sectors and subsectors

\begin{tabular}{|c|c|c|c|}
\hline Areas & Sectors & Subsectors & Characteristics \\
\hline \multirow[t]{4}{*}{$\begin{array}{l}\text { Main fields } \\
\text { of art }\end{array}$} & Staged art & $\begin{array}{l}\text { theatre, dance, } \\
\text { music, opera }\end{array}$ & \multirow{4}{*}{$\begin{array}{l}\text { Nonindustrial activities. Products } \\
\text { are prototypes and have a "potential } \\
\text { of securing with the copyright", i.e. } \\
\text { are based on a creation which could } \\
\text { be a subject of the copyright, but is } \\
\text { not systematically protected (how it } \\
\text { takes place in case of the handicraft } \\
\text { or some productions from the field } \\
\text { of staged or visual arts) }\end{array}$} \\
\hline & Visual art & $\begin{array}{l}\text { painting, sculpture, } \\
\text { craft }\end{array}$ & \\
\hline & Media art & $\begin{array}{l}\text { artistic installations, } \\
\text { film, digital art } \\
\text { computer }\end{array}$ & \\
\hline & Literature & $\begin{array}{l}\text { lyric poetry, } \\
\text { narrative, drama }\end{array}$ & \\
\hline \multirow{5}{*}{$\begin{array}{l}\text { Industries } \\
\text { of the } \\
\text { culture }\end{array}$} & \multicolumn{2}{|c|}{ The film and the video } & \multirow{5}{*}{$\begin{array}{l}\text { Activities of industrial character, set } \\
\text { to the mass reproduction. Products } \\
\text { are subjected to copyright. }\end{array}$} \\
\hline & \multicolumn{2}{|c|}{ Television and radio } & \\
\hline & \multicolumn{2}{|c|}{ Video games } & \\
\hline & Music & $\begin{array}{l}\text { record market, live } \\
\text { concerts, the income } \\
\text { from the title of the } \\
\text { copyright }\end{array}$ & \\
\hline & $\begin{array}{l}\text { Books and the } \\
\text { press }\end{array}$ & $\begin{array}{l}\text { the publishing } \\
\text { market and press }\end{array}$ & \\
\hline \multirow[t]{3}{*}{$\begin{array}{l}\text { Creative } \\
\text { industries }\end{array}$} & Design & $\begin{array}{l}\text { fashion, graphics, } \\
\text { interiors design, } \\
\text { functional design }\end{array}$ & \multirow{3}{*}{$\begin{array}{l}\text { Activities not necessarily of } \\
\text { industrial character and can be } \\
\text { prototypes. Products are subjected } \\
\text { to copyright, but can also be a } \\
\text { subject of other intellectual property } \\
\text { laws (e.g. trademark), } \\
\text { creativity(creative abilities and } \\
\text { people deriving from the artistic } \\
\text { environment and industries of the } \\
\text { culture) is essential to functioning } \\
\text { of beyond cultural sectors }\end{array}$} \\
\hline & \multicolumn{2}{|l|}{ Architecture } & \\
\hline & \multicolumn{2}{|l|}{ Advertisement } & \\
\hline $\begin{array}{l}\text { Related } \\
\text { Industries }\end{array}$ & \multicolumn{2}{|c|}{$\begin{array}{l}\text { Manufacturers of computers, } \\
\text { Manufacturers of MP3 players ,industry } \\
\text { of mobile communications and others. }\end{array}$} & $\begin{array}{l}\text { It involves a lot of various } \\
\text { economic various sectors, which } \\
\text { are dependent on previous "areas" }\end{array}$ \\
\hline
\end{tabular}

(Source: own study) 
Using the value chain, introduced into economics in 1985 by Michael Porter in order to describe economic processes, is one of the points of view on creative industries. The value chain in relation to creative industries, is begun with authors and the cultural institutions, drags further through producers of different kind and distributors of cultural products and ends on recipients, i.e. a widely understood audience. In a perfect case in every chain link a value added of a kind is made, making the product better fitted to the recipient. In fact he however, it can happen, that we deal with deducting the value in the chain, rather than with adding. Figure 2 shows the model value chain for the music industry.

\section{Figure 2 Value chain for the music industry}

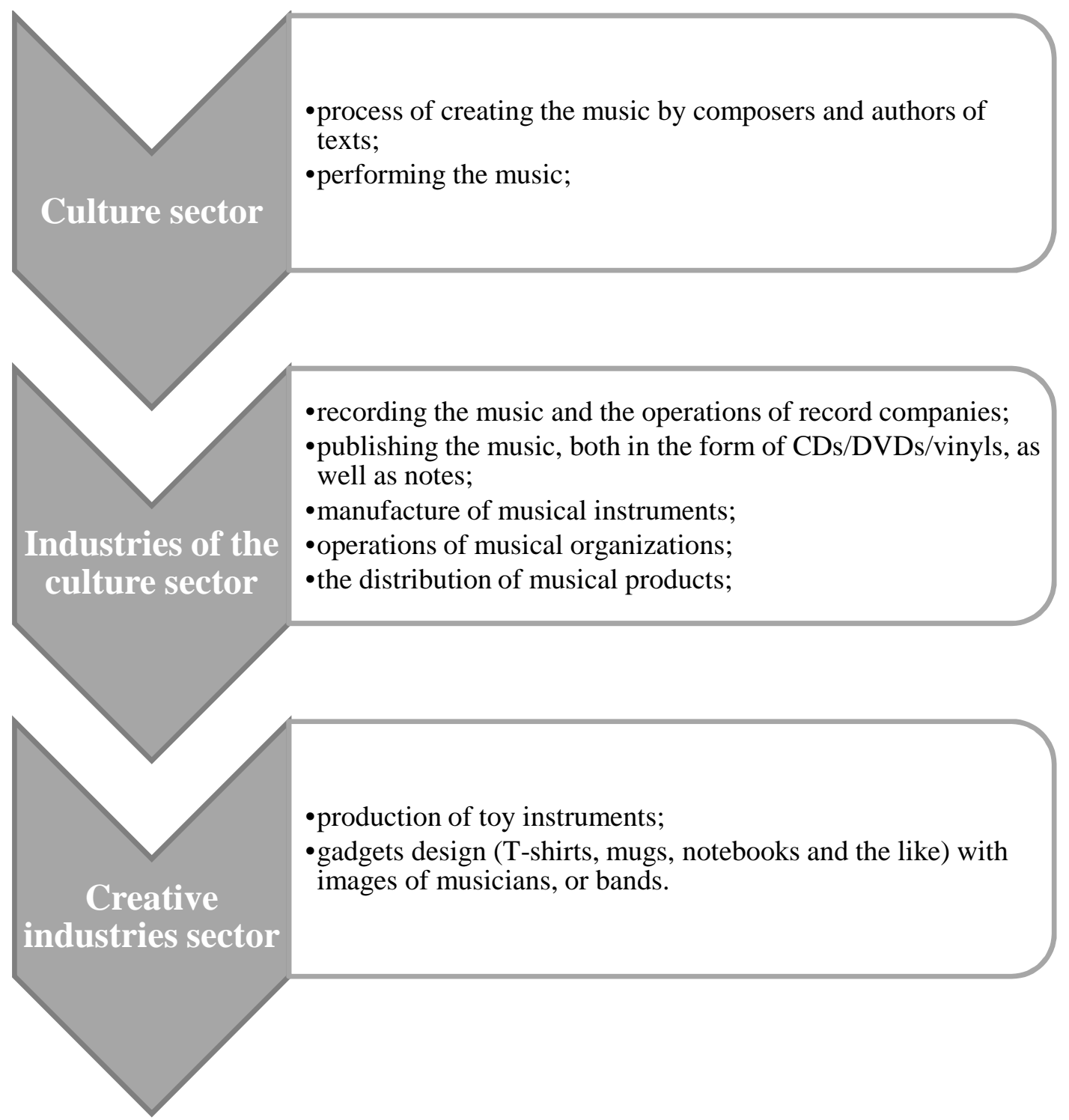

(Source: own study)

This approach assumes the commercialization of the cultural production, that - in most cases means assumption on massive nature of recipients. Figure 3 shows relations between the culture, industries of the culture and creative industries. 
Figure 3 Relation between the culture, industries of the culture and creative industries

INDIVIDUAL AUTHORS/INSTITUTIONS OF THE CULTURE

\begin{tabular}{|c|c|}
\hline $\begin{array}{l}\text { Artistic creativity } \\
\text { (e.g., musical, literary, plastic) }\end{array}$ & $\begin{array}{l}\text { Activity of the institutions of the culture } \\
\text { (e.g. theatres, operas, Philharmonic Orchestras, } \\
\text { museums, libraries, community centres) }\end{array}$ \\
\hline \multicolumn{2}{|c|}{ INDUSTRIES OF THE CULTURE } \\
\hline $\begin{array}{l}\text { Production } \\
\text { - } \\
\text { - } \text { publishing and press industry } \\
\text { - } \text { audio-visual and movie industry }\end{array}$ & $\begin{array}{c}\text { Distribution } \\
\text { (e.g. distribution, sale of newspapers, } \\
\text { books, CDs, DVDs, showing movies, the } \\
\text { trade in antiques) }\end{array}$ \\
\hline \multicolumn{2}{|c|}{ CREATIVE INDUSTRIES } \\
\hline $\begin{array}{l}\text { Production, artistic work } \\
\text { (e.g. specialist design - creating software - } \\
\text { computer games, multimedia, photographic } \\
\text { services, production of toys) }\end{array}$ & $\begin{array}{l}\text { Distribution, promotion } \\
\text { (e.g. advertisement - advertising agencies. } \\
\text { information agencies, organisation of trade } \\
\text { fairs, conferences. exhibitions) }\end{array}$ \\
\hline
\end{tabular}

(Source: own study)

Other way of defining creative industries is a model of the copyright (World Intellectual Property Organization copyright model), which is based on industries involved directly or indirectly in preparing, production, issuance and distribution of materials protected by copyright. In such approach this intellectual law is an essence of creativity in the process of manufacturing of a good or service. Depending on the form of using the copyright, three groups of creative industries contributing to the sector of creative economy, are singled out in this model (Klasik, 2010):

- core creative industries protected by copyright (among others, the advertisement, the film and the video, music, staged arts, the publishing market),

- interdependent creative industries protected by copyright (among others, data carriers, musical instruments, photocopiers),

- creative industries partly protected by copyright (architecture, fashion, design, toys).

\section{THE CULTURAL SECTOR AND CREATIVE INDUSTRIES IN POLAND}

The cultural sector in Poland is very abounding and diversified. It is characterized by not only a substantial amount of cultural entities, but also by a multitude of forms of their organization. It is possible to divide this area into three subsectors: public (national and self-government), private and non-profit. Numerous institutional and non-institutional forms of conducting cultural activities 
appear. This sector gains significance in Poland every year, what is attested by an increase in household expenditure to products of the sphere of the culture (Figure 4).

Figure 4 Average per capita expenses on culture, in Polish households in 2000-2012

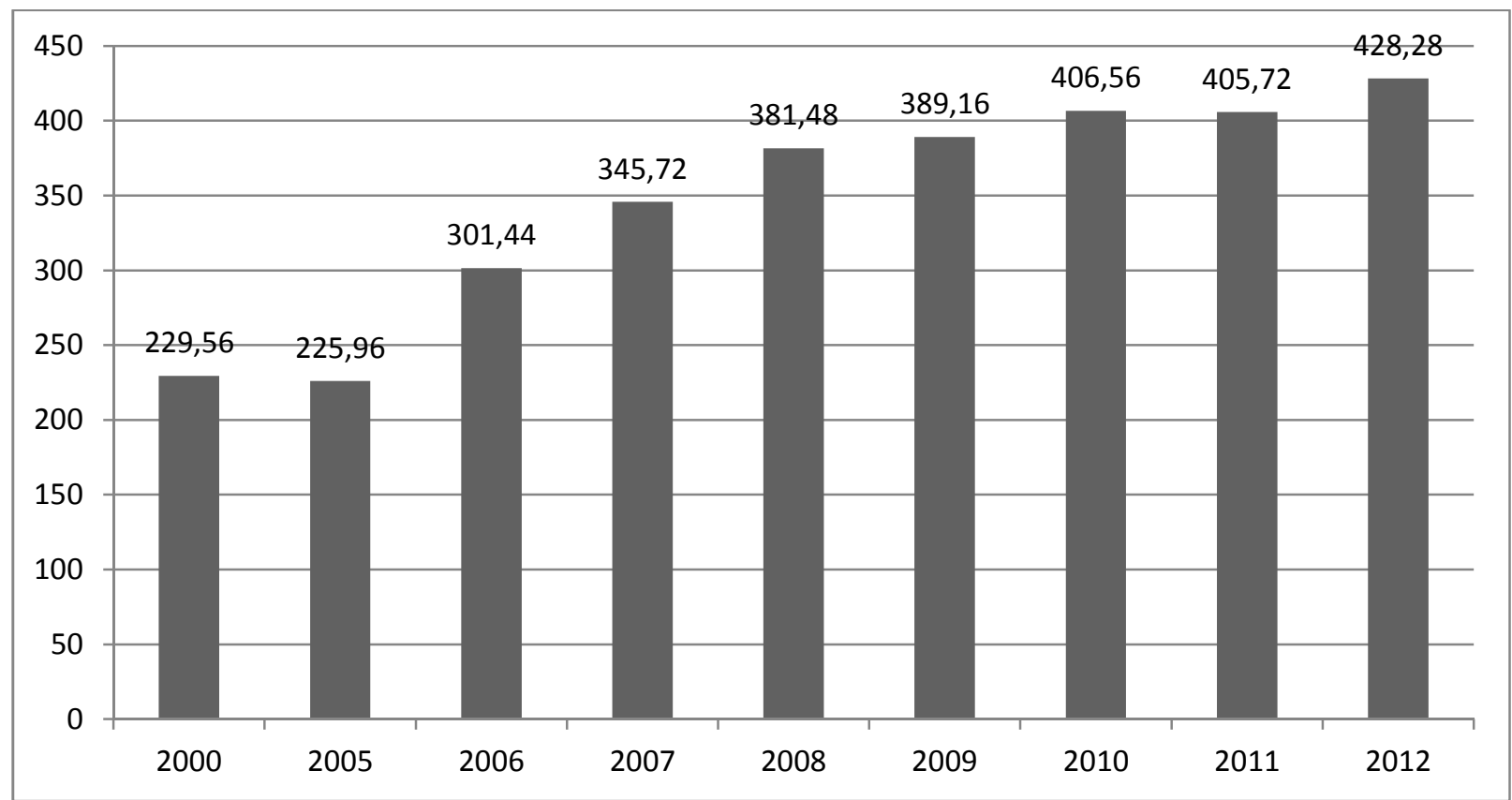

(Source: own study based on „Culture in 2012 - statistical information and elaborations”, Central Statistical Office, Warsaw 2013: 115)

In Poland, industries of the culture are an important component of the cultural sector what effects in a richer and more diverse cultural offer (Figure 5, Table 2), to which an access is facilitated by the developed network of the cultural institutions, modern technologies and media.

\section{Figure 5 Structure of expenses of households on the culture in Poland in 2012}

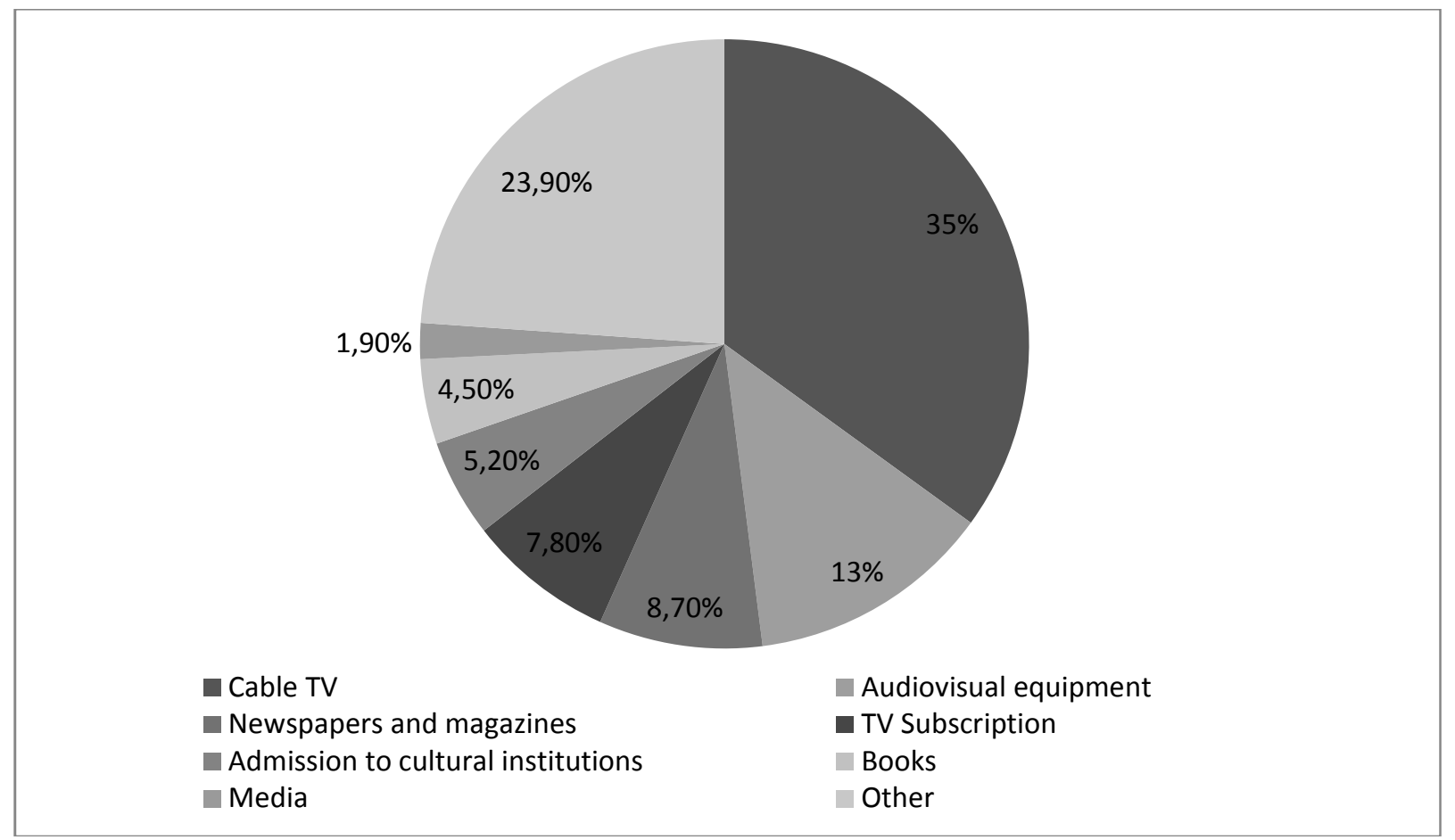


(Source: own study based on „Culture in 2012 - statistical information and elaborations”, Central Statistical Office, Warsaw 2013: 115)

The Institute for Structural Research in Warsaw separated industries of the culture from creative industries. This separation was presented in Table 2.

Table 2. Industries of the culture and creative industries in Poland according to the Institute for Structural Research

\begin{tabular}{|c|c|c|}
\hline & $\begin{array}{c}\text { Industries } \\
\text { of the } \\
\text { culture }\end{array}$ & $\begin{array}{l}\text { Creative } \\
\text { industries }\end{array}$ \\
\hline Publishing & + & + \\
\hline Reproductions of written media & + & + \\
\hline Production of toys & & + \\
\hline Other retail trade - trade in antiques & + & + \\
\hline Sale of newspapers, books, music and video recordings & + & + \\
\hline Services of cable televisions & + & + \\
\hline Issuing of the software & & + \\
\hline Specialist design $\backslash$ Other designer services & & + \\
\hline Professional photographic services & & + \\
\hline Architectural services & & + \\
\hline Advertisement & & + \\
\hline $\begin{array}{l}\text { Activity associated with the organisation of trade fairs, } \\
\text { exhibitions and congresses }\end{array}$ & & + \\
\hline $\begin{array}{l}\text { Creating, distribution, showing films, recordings of films } \\
\text { and of TV programmes }\end{array}$ & + & + \\
\hline Audio and musical recordings & + & + \\
\hline Broadcasting programmes & + & + \\
\hline $\begin{array}{l}\text { Literary artistic work, artistic work, activities of the institutions } \\
\text { of the art }\end{array}$ & + & + \\
\hline Information agencies & & + \\
\hline Libraries, museums and historic buildings & + & + \\
\hline
\end{tabular}

(Source: Economic meaning of the cultural sector. Introduction to the problem analysis. Final report, Institute for Structural Research, Warsaw 2010)

The results of research conducted by the Institute for Structural Research in Warsaw show, that the biggest industries of creative sectors in Poland are: advertisement, publishing (5 bn PLN both), and 
broadcasting programmes (3,9 bn PLN). As for employment, the most persons deal with the literary artistic work, artistic work, and also work at institutions of the art, in libraries, museums and the advertisement (Figure 6).

Figure 6 Employment in creative industries according to industries in Poland in 2008 (the number of people)

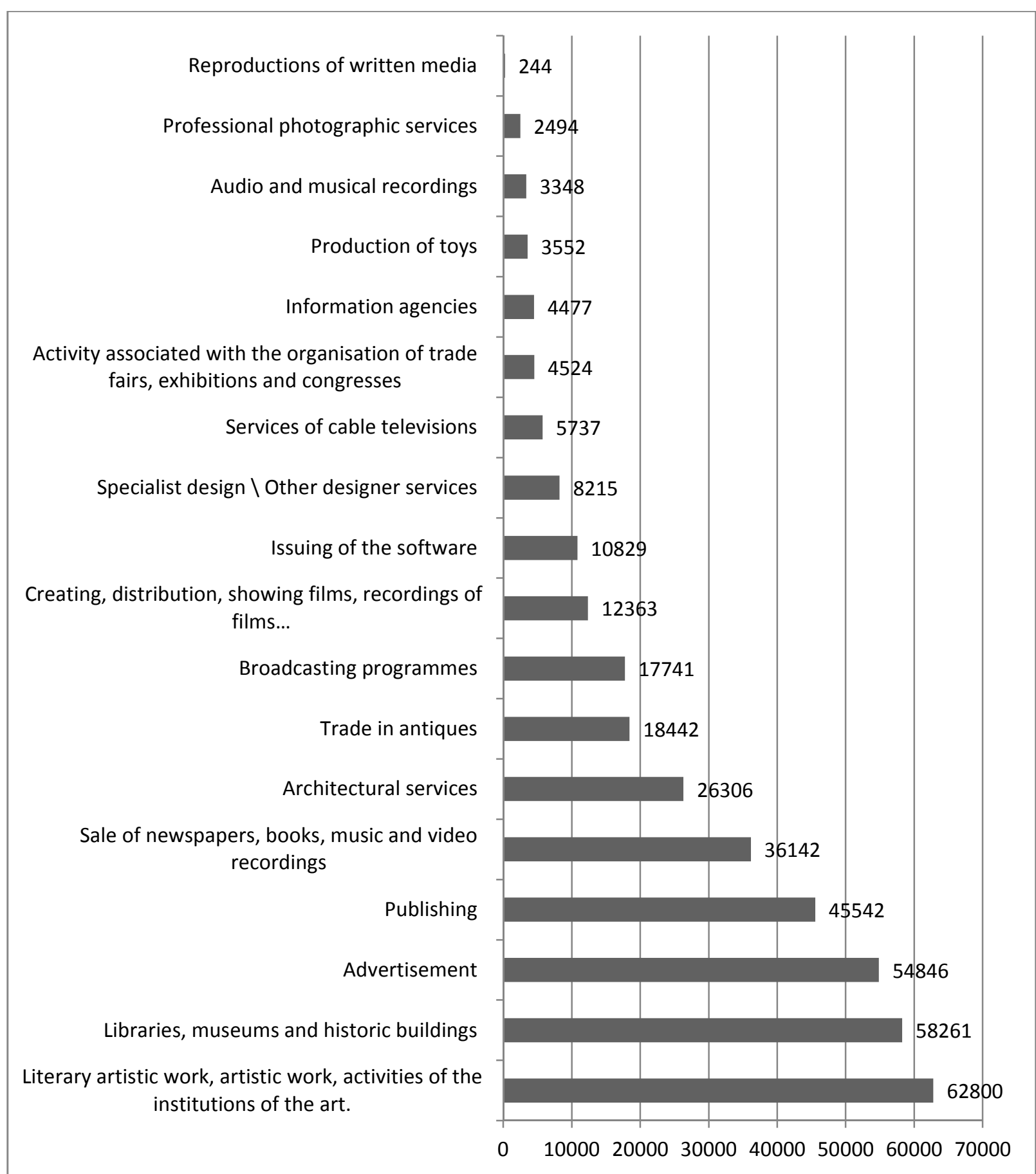

(Source: Economic meaning of the cultural sector. Introduction to the problem analysis. Final report, Institute for Structural Research, Warsaw 2010)

The participation of creative industries in creating the gross value added in 2008 is circa 2.5\%, while the traditionally understood cultural sector has circa $1.5 \%$ of this value (see Figure 6). Gross value added (GVA) should be understood as the value of products and services produced by enterprises or the sector, reduced by the intermediate consumption incurred in relation with its 
production. A gross value added is a measure directly connected with the gross domestic product $($ GVA + taxes - subsidies for the production $=$ GDP $)$. Creative industries compared with the cultural sector also generate more places of employment, which is very essential because of a constantly high unemployment rate in Poland.

\section{Figure 7 Participation of value added and employment in the cultural sector and creative industries in total value added and employment in 2008 (in \%)}

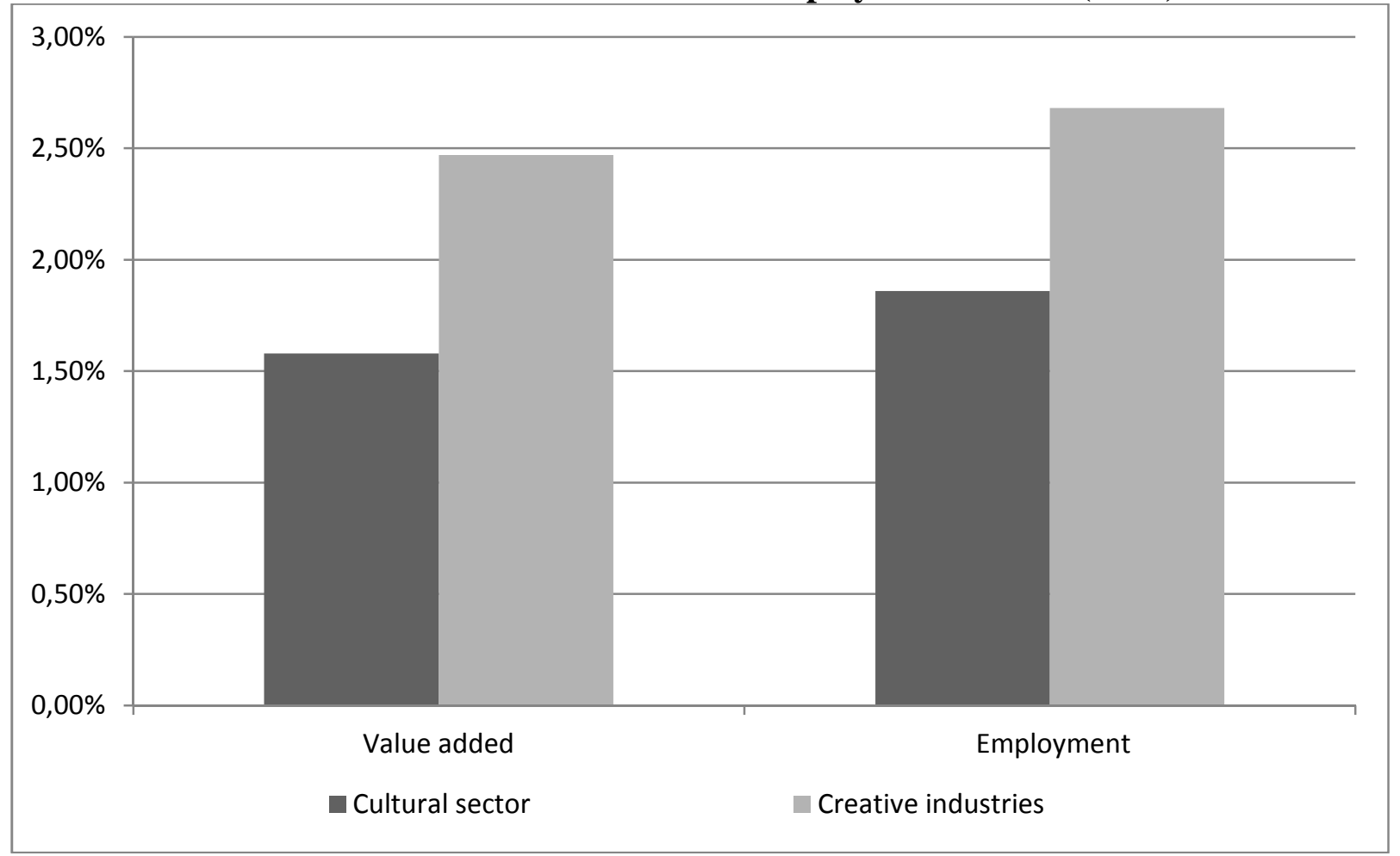

(Source: Economic meaning of the cultural sector. Introduction to the problem analysis. Final report, Institute for Structural Research, Warsaw 2010)

The technical potential, the management and the financial back in creative industries in Poland influence the type and character of their market offer. The superficial evaluation of this industry already however, allows to think that it is best organised and most effective sector on the Polish market of cultural goods and services. Industries of the culture, creative industries being in private hands in over $90 \%$, are an elastic and dynamic area, quickly responding to social needs.

\section{CREATIVE INDUSTRIES AS A FACTOR STIMULATING THE SOCIO-ECONOMIC DEVELOPMENT OF REGION}

The estimates concerning the participation of the sector of creative industries in the economy are conducted by a lot of organizations. According to calculations of the European Commission the sector of industries of the culture and creative industries in countries as, among others, Poland, the Czech Republic, Hungary or Slovakia produces on average c 2\% GDP altogether. In the entire European Union, creative sectors employ over the 3\% of all employees (KEA European Affairs, 2010). Growing significance of creative industries in domestic economies including regional economies, translates both for developing enterprising and creative behaviours of residents of the region, and to the improvement in its competitive position. It also increases attractiveness of the region for current, as well as future residents, tourists and investors. It is possible to notice the positive connection between the development of creative industries and the social-economic development of the region. These industries are an analogous development driving force, to 
agriculture, which was responsible for the growth in the twentieth years of the 20th century, industry in fiftieth and sixtieth years, and in the last two decades - the sector of telecommunications and computer sciences. And so, creative sectors are a generator of new solutions, which transfer to other branches of economy and are adapted or modified there (Smoleń, 2003).

Figure 8 Influence of creative industries on the development of the region

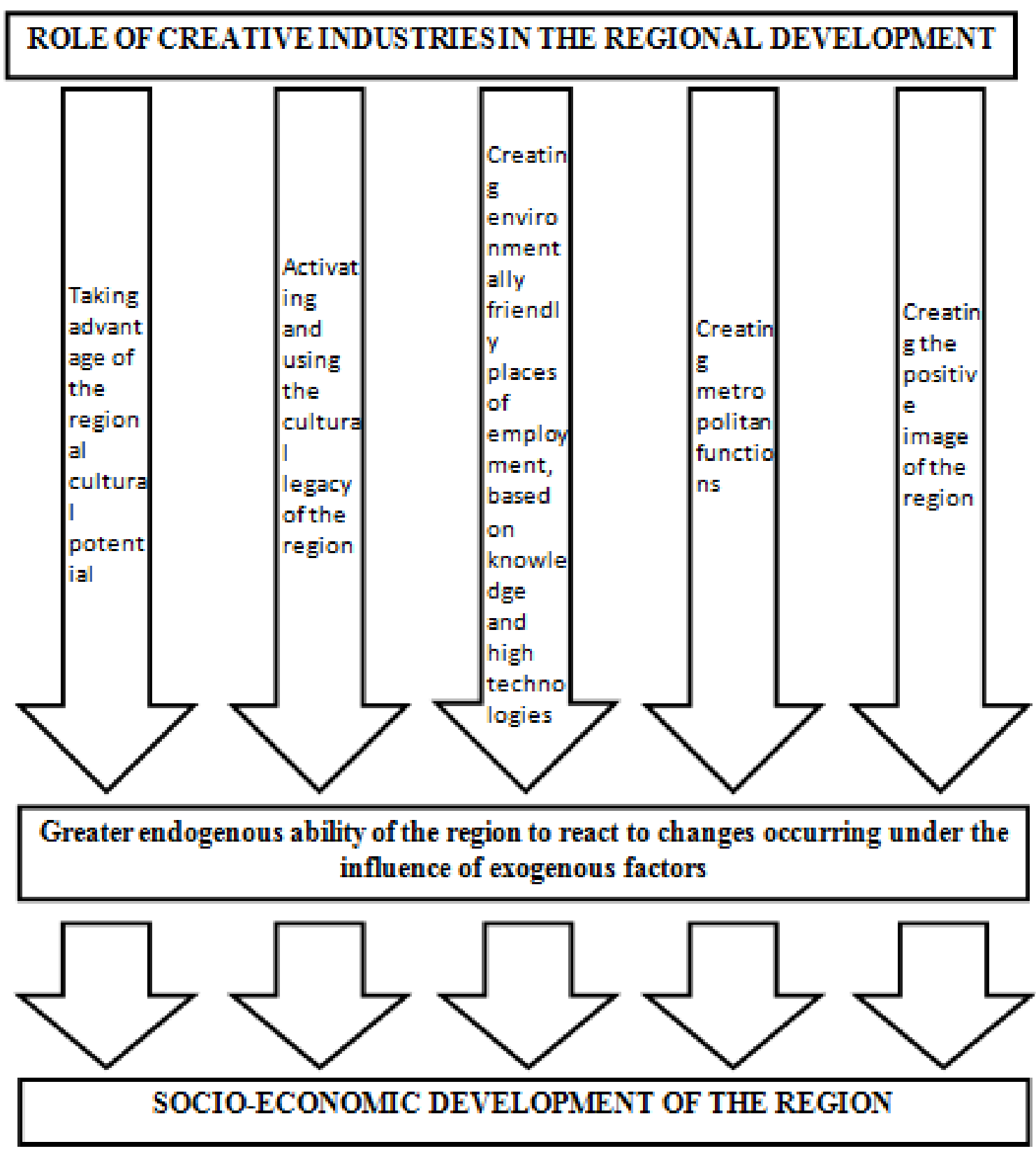

(Source: own study)

Creative industries can have a positive effect on a development of internal regional potential without any harmful effects for the culture (artistic creativity). They depend to a great extent on traditional and cultural diversity, from the know-how and innovative networks existing in Polish regions. The wealth and cultural diversity of Polish regions are a product of centuries of work of creative artists, craftsmen, technicians and their customers. Creative industries are based on this potential and at the same time, they contribute to its future development. They represent the 
combination of economic sectors which, to a large extent, depend on spatial location, and for many reasons and for many reasons must pay a great attention to it. Diverse subsectors of creative industries, where small and medium-sized enterprises dominate, provide many possibilities of creating of new places of employment, which are deeply rooted in local environments and regional networks. In the age of globalization, products and services which creative industries provide, emphasize the regional profile and have a positive effect on conditions underlying the general socio-economic development.

\section{CONCLUSIONS}

Cultural sector, ranked previously among the so-called sphere of public services (creating costs, rather than economic benefits), more and more leaves this sphere. Undergoing the gradual commercialization and "industrialization" of production, it becomes an independent field of management, increasing the gross domestic product, building new profitable places of employment. An information-telecommunications revolution and new media, thanks to which costs of processes of copying and distribution radically lowered, became the driving force of this process of privatizing and industrializing the culture. It is possible to analyse the significance of the culture and the influence of creative industries on the development of the region from different points of view. In conclusion, it can be assumed that the significant and major planes of impact of creative industries on socio-economic development of the regions in Poland include:

- direct impact on the labour market by building environmentally friendly places of employment, based on knowledge and high technologies - on account of innovation, permanent production of new goods and services, creative industries are one of most dynamically developing sectors of the labour market at the moment;

- creating products for other departments (branches of economy), what contributes indirectly to an increase in the number of jobs in sectors complementary to the sphere of the culture tourism, recreation, education. The culture works in fact for other sectors. A national legacy can be an example, which in many, also poorly developed countries, is a flywheel of the development of tourism industry;

- rise in local budget revenues, directly through the sale of goods and services of the culture on the internal and external market, and of indirect profits - property taxes, personal income taxes and company income taxes, and through profits generated in complementary industries;

- factors of investment attractiveness of the region (Bilbao effect);

- an element of the restoration and the revitalization of municipal and country space and postindustrial objects. The revitalization contributes to the improvement of quality of life of residents, and the economic boom as well as the reconstruction of social bonds;

- help in creating the positive image of the region;

- raising the level and qualities of life, what transfers into attraction of the domicile, contributes to attracting and holding creative people who have high qualifications;

- the way to fight against so-called municipal illnesses - weakening social bonds or social pathologies.

Creative industries are a peculiar area of activity of a man, which gain significance every year. Two forces meet here: culture and economics, what provokes for asking questions, in what way to draw from the culture so that it is transferred into the social-economic development of the region. Creative industries which not only contribute to the growth in the economy of the region, but participate in the direct funding of the culture, seem to be a good solution. They finance both valuable artistic events, as well as enable many authors, musical, drama authors and visual artists to realize their artistic aims. It is worthwhile to remember, that every attempt to separate the culture from creative industries gives rise to adverse effects both for the culture, and for its industries. 
Interdependences between the culture subsidized by the state and industries of the culture or creative industries are based not on the competitiveness but rather on their complementary characters. Developing and supporting creative industries, industries of the culture should be included in the development program for Poland. The benefits of having a well-functioning creative industries can be seen on the example of countries such as: the United States, Germany and Austria. Unfortunately, the development of these industries in Poland is hampered by the lack of a coherent, integrated strategy for the development of creative industries at micro and macro levels. The situation is further complicated by an inadequate protection of intellectual property, extremely aggressive piracy and very strong foreign competition. However, this should not discourage taking an action; on the contrary, all adversities should be overcome as quickly as possible.

\section{REFERENCES}

Adorno, T. W. (1991) The Culture Industry - selected essays on mass culture. Routledge London. Caves, R.E. (2000) Creative industries. Contracts between art and commerce. Harvard University Press Cambridge.

Culture in 2012 - statistical information and elaborations (2013) Central Statistical Office in Warsaw.

Dyczewski, L. (1993) Kultura polska w procesie przemian. Katolicki Uniwersytet Lubelski w Lublinie

Economic meaning of the cultural sector. Introduction to the problem analysis. Final report (2010) Institute for Structural Research in Warsaw.

Grad, J., Kaczmarek, U. (2005) Organizacja i upowszechnianie kultury w Polsce. Wydawnictwo Naukowe UAM w Poznaniu.

Grzegorczyk, A. M. (2003) Sponsoring kultury. Oficyna Wydawnicza ASPRA-JR w Warszawie.

Ilczuk, D. (1995) Sektor nonprofit w kulturze. Instytut Kultury w Warszawie.

Ilczuk, D., Misiąg, W. (2003) Finansowanie i organizacja kultury w gospodarce rynkowej. Instytut Badań nad Gospodarką Rynkową w Warszawie.

Klasik, A. (2010) Od sektora kultury do przemysłów kreatywnych, Od przemystów kultury do kreatywnej gospodarki, Gwóźdź, A. (red.), Narodowe Centrum Kultury w Warszawie.

Kłoskowska, A. (1983) Kultura masowa. Polskie Wydawnictwo Naukowe w Warszawie.

Kmita, J. (1982) O kulturze symbolicznej. Centralny Ośrodek Metodyki Upowszechniania Kultury w Warszawie.

Kolb, B. M. (2005) Marketing for cultural organisations. New strategies for attracting audiences to classical music, dance, museums, theatre and opera. Thomson Learning.

Kopczyńska, M. (1993) Animacja społeczno-kulturalna. Podstawowe pojęcia i zagadnienia. Centrum Animacji Kulturalnej w Warszawie.

McCarthy, K.F., Brooks, A., Lowell , J., Zakaras, L. (2001) The performing arts in a new era. Rand.

Sargeant, A. (2004) Marketing w organizacjach non profit. Oficyna Ekonomiczna w Krakowie.

Smoleń, M. (2003) Przemysły kultury - wpływ na rozwój miast. Wydawnictwo Uniwersytetu Jagiellońskiego w Krakowie.

Sobocińska, M. (2008) Zachowania nabywców na rynku dóbr i usług kultury. Polskie Wydawnictwo Ekonomiczne w Warszawie.

Storey, J. (2003) Studia kulturowe i badania kultury popularnej. Teorie i metody. Wydawnictwo Uniwersytetu Jagiellońskiego w Krakowie.

Throsby, D. (2010) Ekonomia i kultura. Narodowe Centrum Kultury w Warszawie.

Wojnar, I. (1995) Aktualne problemy edukacji i kultury w Polsce i na świecie. Polska Akademia Nauk w Warszawie.

Wróblewski, Ł. (2012) Strategie marketingowe w instytucjach kultury. Polskie Wydawnictwo Ekonomiczne w Warszawie. 